\title{
Anthós
}

2014

\section{Linking Resilience and Good Governance: A Literature Review}

\author{
Nikki Bedi \\ Portland State University \\ Madilynn Bishop \\ Portland State University \\ Ukiah Hawkins \\ Portland State University \\ Olivia Miller \\ Portland State University \\ Rodrigo Pedraza \\ Portland State University
}

See next page for additional authors

Follow this and additional works at: https://pdxscholar.library.pdx.edu/anthos

Part of the Political Science Commons

Let us know how access to this document benefits you.

\section{Recommended Citation}

Bedi, Nikki; Bishop, Madilynn; Hawkins, Ukiah; Miller, Olivia; Pedraza, Rodrigo; Preble, Anna; and RicoRairan, Angela (2014) "Linking Resilience and Good Governance: A Literature Review," Anthós: Vol. 6: Iss. 1, Article 3.

https://doi.org/10.15760/anthos.2014.15 


\section{Linking Resilience and Good Governance: A Literature Review}

\section{Authors}

Nikki Bedi, Madilynn Bishop, Ukiah Hawkins, Olivia Miller, Rodrigo Pedraza, Anna Preble, and Angela RicoRairan 


\section{Linking Resilience and Good Governance: A Literature Review}

Nikki Bedi, Madilynn Bishop, Ukiah Hawkins, Olivia Miller, Rodrigo Pedraza, Anna Preble, and Angela Rico-Rairan

\section{Introduction}

Natural or manmade shocks and stresses affect communities in a variety of ways. One way that researchers have tried to isolate the conditions that lead to a thriving community in the face of disaster is the study of resilience. Resilience is the capacity of communities in complex socio-ecological systems to learn, cope, adapt, and transform in the face of shocks and stresses. A key part of resilience is the existence of good governance, which Mercy Corps has identified as a process of decision-making that is accountable, transparent, just, responsive and participatory. The pursuit of good governance can be a beneficial strategy, involving the building of both formal and informal institutions and relationships that are implemented at the state, community and individual levels. The purpose of this literature review is to identify the research that exists in a variety of fields that addresses good governance and resilience at these levels.

This literature review specifically focuses on the Sahel region of Africa. As such, particular attention has been paid to literature that either engages the Sahel region directly, or presents case studies and evidence that applies to similar circumstances. Thus, the reviewed literature also includes research that concerns a variety of developing, low-income countries that experience environmental stressors and 
shocks and which, in most cases, are also experiencing political transitions towards more liberalized and pluralistic politics.

The Sahel is a semi-arid biological and geographical multinational climatic transitional region, which demarcates the area between the Sudanian Savanna and the Sahara Desert. Among the nation states, which are partially contained within the Sahel region, are Mauritania, Sudan, South Sudan, Algeria, Burkina Faso, the Gambia, Senegal, Nigeria, Cameroon, Chad, Mali and Niger. (Grove, 1978). Issues of pastoralist and nomadic migration are often in the forefront of discussion relating to the Sahel because of the nature of this region's climate. Due to the potential negative impacts of global climate change in relation to certain aspects of interaction in the Sahel, analyses of socioeconomic and political stability in the region; are of importance to those in the field of international nongovernmental assistance and aid provision (Benjaminsen et al., 2012).

\section{National and Regional Level}

A resilient society is described by Mercy Corps as a community in a complex socio-ecological situation with the ability to adapt and transform for the better, when faced with natural or manmade shocks and stresses (Mercy Corps, 2013). This section of the review will focus on resilience in communities facing such shocks and stresses and how good governance at the regional and national level relates to regional and national success. Good governance at the regional and national levels should combine features such as robustness, redundancy, recovery, conservation, sustainability, and risk mitigation in order to deliver enhanced resilience (Zolli, 2013). The discussion of these vital components, combined with information and study of previous resiliency successes, will be used to develop a clear understanding of how national and regional governance can build resiliency in a specific area. 
National and regional governance tends to have its greatest impact in specific areas, such as environmental policy, infrastructure, finance and economics, and rule of law. This section will examine how state actors might best pursue resilience and enhance strategies of governance in these areas.

We will examine the specific context of Mali, a representative Sahel region country of particular interest to Mercy Corps. In terms of central government structure, as well as efforts in securing rule of law, Mali's conditions are characterized by political instability, corruption and a weak judicial branch. While citizens are free from violent attacks at the polls, this does not promise that rule of law will follow easily. Thurston suggests that human and social security plans should take priority over elections in order to improve governance (Thurston, p. 6).

\section{Social Capital}

Social capital is a valuable concept that helps to show how communities develop the capacity for increasing their economic wealth through civic engagement (Putnam, 1994). Regarding critical and community resilience, civic engagement stands alongside economic and natural resource capital as equally critical (Aldrich, 2012). Three analytical formats have been recognized in order to better compartmentalize and study social capital. These forms are bonding, bridging and linking. Bonding (or, "in-group") social capital has been defined as an understanding between those individuals of similar interest, geographical location or another "key dimension” of similarity. Bridging (or, “cross-group”) capital has been seen as those bonds of trust between individuals that do not necessarily share similarities, yet are at similar levels of status (Kennedy School; Kim et al., 2006). Linking (or, "hierarchical”) capital is then the potential connections that occur across established systems of hierarchy and similarity (Ferlander, 2007). 
In order to establish a resilient system—not just on the state level but with linkages to the community level as well-the Institutional Analysis and Development (AID) framework creates a complex set of rules that can help to organize and control institutions and infrastructure at any level (Clement, p. 129-156).

The set of rules for these institutions are represented in levels. The broadest level is the constitutional level, which determines how the rules at the collective level are made. The collective-choice level determines how rules at the operational level can be changed. The operational level governs how decisions of infrastructure or institution management are implemented (Clement, p. 129-156). All of these levels function in order to regulate the action arena that involves the actions of individuals. These levels create redundancy within government institutions in order to make recovery easier if one level is destroyed or made useless by natural or manmade disaster. These levels can be useful for government structure in a country like Mali because it can improve institutional and infrastructure organization if needed and help sustain it, if it already exists.

A weak judicial branch and a shortage of legal personnel has led to scarce or inaccessible legal representation for defendants in court, especially in rural areas (American Bar Association, 2013; US State Dept., 2012). With regards to import trade, complaints by foreign companies of illegal payments at the border have continued; business and property rights are inconsistently enforced, making economic activity and development more difficult (State Dept., 2012). Finally, national efforts have been criticized as unhelpful or unable to protect those who are thought of as among the most vulnerable of Malians from civil rights abuses and discrimination. Only fifty labor inspectors are available to inspect workplaces for violations, including serious abuses, such as exploitation of forced labor, especially with child labor. 
Malians living with AIDS and HIV cannot depend on law enforcement to shield against societal abuse.

The added stress of climate change and disaster on a country like Mali can cause strain on the government structure. Because of that added strain, the government needs to learn to cope with environmental impact in a resilient way, in order to have a positive environmental impact at the state level that with eventually link to the community (Aldrich, 2012). If the state can have a positive impact in a way that creates linkages of social capital between the various levels of governance they might be able to have a more effective structure (Aldrich, 2012).

In order for a state government to successfully save resources during comfortable climate times, it must communicate effectively and efficiently with local government and promote participatory planning and conservation (Brown, p. 171-185; Clement, p. 129-156; Mirumachi and Van Wyk, p. 25-38). In order to develop a system that is sustainable, through good and bad times for natural resources, national governance must involve and communicate with stakeholders (Mirumachi and Van Wyk, p. 25-38; Brown, p. 171-185). If a party is interested enough, the state may be able to drawn them in and convince them to invest in order to receive some benefit for the work done (Mirumachi and Wan Wyk, p. 25-38). The risk is that if the state does not communicate with local governments and stakeholders efficiently, the stakeholders may withdraw and leave a project largely unfunded (Mirumachi and Wan Wyk, p. 25-38). The literature argues that if a project, such as cross-border water distribution in South Africa, were to rail because of unreliable stakeholders, it would lead to a government that cannot pay for a resource that is needed during climate disasters like drought (Brown, p. 171-185):

Without good economic policy, it is difficult to maintain a system at the state level that is resilient and can be robust 
Anthós, Vol. VI, Issue 1

and sustainable in order to function well to mitigate risks and recover quickly. (Brown, p. 171-185)

Using reliable stakeholders from sawmills and irrigation boards could lead to success that would allow for potable water distribution throughout more than just South Africa (Brown, p. 171-185). With the ability to create and save natural resources, through the national level, the governance structure can mitigate many risks and be better prepared for crisis (Clement, p. 129-156). The operationalization of conversation, sustainability and mitigation of risks within the idea of widespread environmental impact is not always clear cut, and certain parts may vary, such as which stakeholders to use or which local government agencies to communicate through, depending on the issue (Clement, p. 129-156; Brown, p. 171-185). It is clear that resilience depends on good governance at a national level (Brown, p. 171-185; Clement, p. 129-156; Mirumachi and Van Wyk, p. 25-38). Communication and resource management can be used together to disseminate resilience through a country from the top down (Brown, p. 171-185).

The international economy of Mali is another area where shocks and stresses arise. The cotton and gold industries are the main areas of focus for the export economy, but these exports are placed under constant pressure by international pricing and supply demands.

Economic instability can be a major threat to resilience. Good economic policy is needed to mitigate such risks and recover quickly (Briguglio et al., p. 229-247). Many countries that have difficulty being economically resilient suffer from too much dependency on needed imports and export the majority of the goods made or grown in that area (Briguglio et al., p. 229-247). This causes the country to be too vulnerable to changes in the global economy. Cotton farmers have been highly productive with their yields, but must compete with international pricing which has been affected by contributions from 
larger, richer countries, especially those which are the largest cotton producers in the world. If a country is going to be economically resilient, it must have a dependable government to nurture economic resilience (Briguglio et al., p. 119-247).

The central government's role in a "robust-yet-fragile" ("RYF") agricultural export sector includes its role in rebuilding and reorganization (Doyle, qtd. in Zolli, p. 27). One case study of women farmers describes how informal trading networks provide seeds in times of scarcity: informal traders meet the needs of farmers better than the central government, especially at important moments in times of scarcity (IFPRI, 2008). Yet fragility remains and the central government may be better placed to address the unknown effects of seed scarcity in order to build resilience.

The central government is in the ideal position to track and spread accurate and reliable information about international market prices that could negatively impact farmers. Providing such information freely to stakeholders would allow farmers to make informed decisions about how to proceed with their inputs and crop yields. Additionally, cotton, which is produced by Malian farmers, could still fetch a living wage if a price clearing house-a cluster of informed manufacturers - could construct a process which would help make up for lowered cotton prices and allow farmers reasonable returns to continue investing in inputs. A positive feedback loop could result from well-timed, relevant and relatable information. Information that farmers and livestock managers find helpful in making decisions that could boost their absorptive capacity.

Economic measures of Mali have long focused on macroeconomic programs and growth to raise living standards. However, inherited borders broke up natural waterways, overlapped traditional travel corridors with state boundaries, and split “Africa's many surplus food-production zones from the cross-border deficit markers they would most naturally serve” (Haggblade, p. 150). 
Additionally, economic integration must contend with poor national governance, multiple languages, state protocols, and issues such as border controls and fee negotiations. The resulting "endemic small country problem" creates a built-in disadvantage that policy makers must confront in order to craft useful ways to address cycles of drought and food shortages. The jumble of borders, which cut across the traditionally regionally communicative communities, also takes away incentives for states building a more effective infrastructure. However, infrastructure projects that could improve border crossings must be entirely financed by one country's share of aid. It cannot be a joint venture by the countries which both benefit. Because international aid structures do not encourage join aid assessments, infrastructure, which is too overwhelming for one state, is left unattended, and transport logistics and costs continue to affect food delivery to local markets (Haggblade, 2013).

Remittances from Malian émigrés have also played an increasingly important part in economic activity within the country and, like other issues, can be better governed by the national state in order to enhance resilience (Gupta et al., 2009). Rule of law will again determine the effectiveness of remittances in Malian development: elements of corruption might intercept and prevent remittances from reaching the households to which they were intended. Household-level and community-level economic activity benefit from lack of interference in the transmission of remittances. A study in e-governance from Zambia suggests that governments could benefit from cell phone use in sub-Saharan economies (Nyirenda et al., 2010). Although landline use remains low due to a lack of infrastructure and high costs, mobile phone ownership and use has risen to rates of approximately 70 per 100 persons (CIA Factbook, 2012). Cell phone use has been studied as a means to greatly ease and hasten remittance transfers and local market transactions (Chipcase, 2009; Batchelor, 2012; Islam et al., 2010; Harvey et al.). 
Additionally, cell phone use throughout Africa is being examined as another means of communication from the national government to its citizens (Hermanns, 2008; Harvey et al., 2010). Further, scholars have pointed out that a careful examination and assessment of cell phones in connecting social networks and enabling access to information have yet to provide a clear picture of the potential for cell phones in governance (Harvey et al., 2010; Alozie et al., 2011).

National level state policy towards women has also gained attention towards of Malian governance towards gender equity. In 2011, the National Assembly voted to pass a revised version of the law which removed many rights for women, including property rights and full parity in family law decisions (Diarra, 2012). Political participation for women in the Parliament is currently at about 9.52 percent (Parline, 2014). Substantive representation of women at the national level has yet to yield greater gains for women in terms of education, socioeconomic status, and access to resources, especially as livelihoods in Mali are confronted by pressures to change. As globalization continues to increase international interdependencies and agreements, international pressure to align Malian domestic law with international protocol, such as the gender equity goals set by the United Nations, could continue to rise.

\section{Community Level}

A community is resilient when it can function and sustain critical systems under stress, adapt to changes in the physical, social, and economic environment, and be selfreliant if external resources are limited or cut off. (Frankenberger et al., 2013)

Social capital can be seen as features of social organization such as networks and norms that facilitate mutually beneficial coordinated 
action (Evans and Syrett, 2007). Two different schools of thought exist regarding social capital. The first is represented in the works of Coleman (1988; 1990), Uphoff (2000), and Putnam (1993), and is referred to succinctly by Evans and Syrett (2007) as "structural social capital," an emphasis in networks, organizations and linkages through which information and norms are conveyed, and social capital based around cognitive values such as shared norms, values, trust, attitudes and beliefs.

The other method for measuring, analyzing and seeing social capital comes from Aldrich (2012), as identified in (Frankenberger et al., 2013). There are three types of social capital: bonding, linking, and bridging. "Bonding," in social capital, refers to the bonds between community members. It involves principles and norms such as trust, reciprocity, and cooperation. In the disaster context, this is drawn on when survivors work closely to help each other to cope and recover. "Bridging" social capital then, connects members of one community or group to other communities/groups, often crossing physical and ethnic boundaries. As Frankenberger et al. (2013) find in Wetterberg (2004), during times of crisis, when one community or group is in need of resources, bridging capital can be drawn upon. "Linking" capital is seen to form trusted social networks between individuals and groups interacting across explicit and institutionalized formal boundaries in society (Frankenberger et al., 2013).

\section{Informal Relationships}

This section of the literature review will examine the key factors that contribute to resilience at the informal community level, and how they contribute to good governance at the informal community level.

In the literature reviewed, several different factors were found to significantly affect resilience at the community level. These include community assets (human, financial, natural physical, political and social capital or 'livelihoods' in Ellis, 2000) or in Goulden et al. 
(2013), the collective capacity of customary institutions, collective action capacities and livelihood diversification. Two major aspects that have been highlighted in the literature as being especially key to building resilience at all levels, were social capital (Aldrich, 2012; Frankenberger et al., 2013; USAID 2012; Ganapati, 2012; Evans and Syrett, 2007; Wetterberg, 2004; Uphoff and Wijayaratna, 2000; Sharp and Smith, 2003; Zolli and Healy, 2012) and collective action, directly (Frankenberger et al., 2013; Molinas, 1998; Pretty and Ward, 2001), and indirectly (Meinzen-Dick, DiGregorio and McCarthy, 2004).

The community level is a critical level at which to build resilience. In many instances, individuals do not have enough resources or power to deal with stressors on their own (Frankenberger, 2014), and those who are the most vulnerable can be helped through strengthening adaption and resilience of communities and institutions (Turner, "Climate Change and Social Resilience: "Adaptive" Conflict in the Sahel," n.d.; Goulden et al., 2013). In addition, not all sources of resilience to the different types of climate stress are available to households all the time, unlike social capital, which is always able to provide resilience (Goulden et al., 2013). In this way, social capital, with its "networks and norms which facilitate mutually beneficial coordinated action," (Evans and Syrett, 2007; Krishna, 2004) is seen to be a key part in this. Social capital and local institutions lower the cost of working together, thus enabling cooperation (Pretty and Ward, 2001). Cooperation in turn is essential for collective action (Zolli and Healy, 2012). 'People have the confidence to invest in collective action, knowing that others will do so' (Pretty and Ward, 2001).

Building up three different types of social capital (bonding, bridging, and linking (Frankenberger et al., 2013) has been found specifically to help households and communities have access to resources or power to help deal with stressors and shocks. 
Trust, one of the building blocks of bonding capital (Frankenberger et al., 2013), reduces transaction costs between people as when trust is there between members in a community, resources used to monitor each other do not need to be used (Pretty and Ward, 2001). Similarly, as (Baland and Platteau, 1996) find, cooperation is unlikely in a society that has a high level of distrust (Pretty and Ward, 2001). Lyon (2000) finds that the first mechanism that builds trust is establishing networks of working relationships.

The most common are is trade partnership, which involves trust if payments are made on time, and reciprocity between the farmer and the buyer in the form of continued buying from the farmer, especially in times of scarcity. The second mechanism by which links are strengthened is through building customer relationships, such as blurring the line between formal and informal working relationships. This may include in-home stays during travel or otherwise (such as the children staying with a trader during their education in the same city), gift giving, naming of the children after the trader, and the trader attending important ceremonies of the farmer's family and contributing money (for funerals or "outdooring," when a newborn baby is first taken outside), visiting the farmer when he/she is sick, or other common celebrations (Pretty and Ward, 2001). The third mechanism is forming links on pre-existing networks. The fourth mechanism is the establishing of an intermediary common to both parties as a way to build trust; for instance, a guarantor in case a debt defaults, elders in the family, or another farmer who is also a close customer of the trader.

Connection between groups may further take place as the following: trading of goods, exchange of information, mutual help, and the provision of loans:

In addition, part of their research found that villagers were able to learn skills, have access to credit, have custom for 
businesses, gain remittances, manage migration, and have reduced risks associated with livelihood activities. (Pretty and Ward, 2001)

In a case study of the adaptive responses to drought and flooding in villages near Lake Kyoga and Lake Wamala in Uganda, (Goulden et al., 2013) found that a resilience strategy used by the community included relying on bonding and bridging capital to seek help from others and borrow food or money. In addition, part of their research found that villagers were able to learn skills, have access to credit, have custom for businesses, gain remittances, manage migration, and have reduced risks associated with livelihood activities. The specific institutions that contributed to the social capital were the local council committees. They advocated on behalf of the victims of the floods to the landlords for access to land to rebuild their homes. Communitybased groups such as fishery management committees also contributed. However, one institution failed due to the lack of bonding capital despite the existence of bridging and linking capital with government officials.

One study which highlights the importance of collective management and action takes the example from India where collective ownership of water resources was replaced by private ownership resulting in resource degradation (Pretty and Ward, 2001). Similarly, a regional comparative study of grazing in India found degradation in those areas where there was a lack of community oversight of grazing (Pretty and Ward, 2001).

Pretty and Ward (Pretty and Ward, 2001) documented local groups, which were formed to manage local resources (watershed/ catchment management; irrigation management; microfinance delivery; forest management; integrated pest management; and farmers' research groups). The area in which these groups managed their resources found increased yield, increased local participation, 
equity of distribution of resources, improved income among households, and improved biodiversity, and cooperation between ethnic groups (Pretty and Ward, 2001) (Uphoff and Wijayaratna, "Demonstrated Benefits from Social Capital: The Productivity of Farmer Organizations in Gal Oya, Sri Lanka,” 2000).

Ganpati (2012) finds that three additional factors to focus on to build social capital include: face-to-face interaction, mobilizing the potential for collection action through local leaders, and having enabling institutions being in place. Face-to-face interaction builds trust and reciprocity among individuals. One way this can be done is through ensuring proximity among disaster survivors by ensuring they stay in their own community following a disaster (versus dispersing) (Ganpati, 2012). Second, building public spaces (e.g. parks and plazas) for face-to-face interaction (Ganpati, 2012). Mobilizing the potential for collection action through local leaders should include leadership-building programs, and enabling institutions in place should ensure citizen participation and social inclusiveness occur (Ganpati, 2012).

The particular vulnerabilities of women warrant attention to the specific effects of social capital their sub-group. These vulnerabilities include (Ganpati, 2012): more deaths of women than men during disasters (Neumayer and Plümper, 2007) and limited access of women and women-headed households to formal relief and recovery mechanisms after disasters which means a longer recovery time (Morrow and Elaine Enarson, 1996). There has been some literature that has studied social capital for women in the context of crises and disasters. The research has found overall that women in particular can benefit from social capital in times of crisis. In particular, Ganpati (2012) found that the beneficial effects of social capital networks after a major earthquake provided women positive psychological rehabilitation and support after the earthquake, empowered them to gain civic consciousness and to express themselves better, enabled 
them to express their dissatisfaction with the gender biases in Turkish society, and helped them overcome the stigma of receiving public assistance (Ganpati, 2012).

Many of the social capital linkages, and collective organizations and networks, have particularly such characteristics, which allow them to fulfill some (if not all) the areas required for good governance. As seen above, groups that were formed to manage natural resources had a participatory and equitable element to them.

While most of the literature has argued for high levels of each capital, there has been some literature which cautions against the use of certain types of capital over others. Studying three case examples from Uganda, (Vervisch and Titeca, 2008) argue that linking capital can negatively impact associations and democratic governance if bonding and bridging capital are not also present. One instance is when the linking gatekeeper (who is the regulator of the flows of information and resources) between the community and the higher levels of governmental institutions does not follow democratic procedures. Further, (Cleaver, 2005) cautions that social capital and collective action may actually reproduce chronic poverty. One constraint that must be overcome in order to achieve collective action involves: For farmers to invest in these approaches, they must be convinced that the benefits derived from group or joint or collective approaches will be greater than those from individual ones (Pretty and Ward, 2001).

Within the community in the business of the provision of international aid for the purpose of relief and development, the concept of resilience has become vital. Not merely content to support communities in times of crisis, international agencies and institutions are recognizing the importance of utilizing their aid dollars in such a way that ensures that basic factors and resource availability, otherwise known as coping capacity, is not the strict focus of their work (Mercy Corps, 2012). Instead many of these agencies, including 
those such major players as the World Bank, Mercy Corps and the US Agency for International Development (USAID; US Dept. of State, 2012), are turning to the recognition that individuals, households and other levels of institutional complexity must be able to adapt in times of situational insecurity. This adaptation includes the shifting of economic focus in order to ensure a return to productivity Pingali et al., S5-S24), as well as adopting new policy frameworks within which to operate that ensure appropriate adherence to standardized metrics of good governance within which these agencies determine the availability of aid (Nanda, 269-283).

The awareness of building resiliency is one that recognizes the necessity of including long-term planning goals in a toolkit of increased scope when addressing the needs of those levels of community which are experiencing protracted crises due to climatic issues and other consequent issues such as migration, food insecurity, ethnic strife and violence (Frankenberger, et. al., 2012). For the sake of this work, the exploration of concepts within the broader understanding of resilience is necessary. The first concept to be explored is that of good governance, more specifically the elements of civic participation and voice (Mercy Corps, 2013) that allow for broad community input and consensus building. The second section of the discussion relates to more specific theoretical discussion in the understanding of building adaptive capacity. The third section relates to the middle of the conversation, wherein these two concepts meet and form a coalescent theory behind practical principles of community resiliency.

Mercy Corps recognizes one of the most valuable tools in the provision of good governance as that of participation in civic affairs of discussion and government by those directly impacted by the decisions occurring therein. Equity of involvement in issues of governance by those of various genders, ethnic, and socioeconomic backgrounds is considered vital to the furtherance of resiliency (Robards et al., p. 415-427). In a study in the U.S. state of Washington, 
the increase of systemic environmental awareness of those directly impacted by the shifting of systemic adaptivity showed an increase in civic literacy and thereby, a greater emphasis toward control by those disenfranchised population (Ballard et al., p. 611-627).

The value of the bridging effect of social capital between disparate social hierarchies is also necessary to understand the role of the community within the discussion of resiliency affected by good governance. In Cambodia, a nation-state with a history of lacking participatory governance, a series of community council elections took place in 2002. This occurrence utilized principles of decentralization, capacity building, awareness of potential for participation, and the enhancing of prospects of sustainability. While involvement of those local citizens wasn't necessarily improved, their awareness of the practical function of those representative councils was (Pellini et al., p. 404-409). If sustainability can be effected and enhanced by the ability of individuals within communities to participate - whether in an direct or indirect fashion - then the value of participation as an element of good governance through the creation of bridging social capital, and within the more broad discussion of resiliency.

Other studies point to the value of the brokers of power within formal institutions (Boyd et al., 2012). Informal power relationships can become established between those holding direct coercive authority, in this case the councils, and those citizens whom they serve. In these situations, it is important to recognize the value of the power brokers, and the role that they play in governance (Lomnitz, 1988). The effect that these brokers play can be positive or negative within the context of the bonds of their communities. The role of the broker can also be played by a spiritual adviser, in the roles of imam or rabbi or pastor (Sheikh, p. 319-322). The importance of recognizing the role of spiritual power brokers and their effect upon the behavior 
of the community cannot be underestimated in the dealings of governance (Guth et al., p. 364-382).

One of the most complicated issues to overcome in areas wherein participation is to be increased is the difficulty in overcoming barriers predicated upon diverse social norms and identities (Wagle, p. 301322; Stoll et al., 2007). These barriers have been shown to have the potential to be overcome through various informal processes, as long as the opposition to the community comes from a source that threatens the wellbeing of groups across classical boundaries. (Hou et al., p. 301-314) The literature available displays that barriers to governance can be overcome in a concerted effort to contextually educate the people about those issues which cause potential harms to economy and wellbeing, involving them in a process which provides for increased participation of communities of all backgrounds.

\section{Formal Government}

The literature reveals a core piece of policy implementation for good governance and resilience is local-level institutions. According to the Good Governance framework of Mercy Corps, formal governments can be held responsible largely for the public service delivery (Allen, 2010). Government is defined as the structures and systems to ensure the effective, efficient, and responsive delivery of these services (Allen, 2010; Frankenberger et al., 2012). One of the key factors of efficient public service delivery is feedback mechanisms and communication between the informal networks and government institutions to develop social capital (Zolli et al., 2013; Aldrich, 2012; Pretty et al., p. 209-227). An effective local government can build networks upward to develop strong transformative capacity through linking capital, and build adaptive capacity through bridging capital to other communities (Zolli et al., 2013; Frankenberger et al., 2012). Author Andrew Zolli argues that healthy feedback mechanisms and a modular structure are necessary for a whole system to function 
resiliently, building trust, so that the health of each link can be kept in check (Zolli et al., 2013).

The literature states that local institutions are more effective at building capacity to help with disaster preparedness when utilizing social capital (DIIS. Working Paper 2010; IFRC; Aldrich, 2012). An example of this is in Skopje, Macedonia, where the city faced threats of earthquakes. To develop a resilience strategy, the government found that an area was increasingly vulnerable to earthquakes when feelings of distrust in a government increased. It was found that social capital, bolstered through programming to increase communication and education, was more important than physical regulations such as law enforcement (Sickmiller; Twigg, 2007). This example demonstrates the strong linking social capital is a necessary step for positive service delivery (Frankembeger et al., 2012; Zolli et al., 2013; Pretty et al., p. 209-227). The relationship between formal institutions to the individual community members illustrates the importance of trust between the local institutions and individuals will impact the effectiveness of resilience programs (Sickmiller; Frankenberger et al., 2012; Aldrich, 2012).

Being able to identify the health of these individual linkages between the federal policies to community-institution policy implementation is essential to evaluate the functionality of a resilient system (Zolli et al., 2013).

The literature supports that the local governments have the clear deliverables of public service, which are often defined by a regional government body, many local institutions may lack training to deliver efficiently (DIIS. Working Paper, 2010; Gallopin, 2007). The relationship between regional and community governments should be carefully managed to ensure that policies developed on the national side are supported during the implementation time (Garden et al., 2005). A case study of this is in Sri Lanka. A national network of offices was set up in response to the tsunamis in 2004 to prepare for 
Anthós, Vol. VI, Issue 1

future disasters (IFRC). A national Disaster Management Centre was established, with each district in Sri Lanka creating its own Disaster Management Coordination Unit. These units then created disaster management committees within each community, with community leaders trained on how to respond (IFRC). This demonstrates the relationship of systems theory and modular structure to community level institutions (Frankenberger et al., 2012; Zolli et al., 2013; Boyd et al., 2012). This approach is a large-scale view that includes the political, social, and environmental landscapes as actors, institutions and the infrastructure in place interact to create the many layers (USAID, 2014).

Modular structures within policy implementation allow for the clear definition of roles of institutions and the ability to replace and rework portions of institutions (Zolli et al., 2013).

\section{Individual Level}

This literature review focuses around resilience and good governance at the individual level in countries with climate stresses, low development and transitional governments. These case studies will allow for the formation of a graphic with connections between good governance and resilience at the individual level, with specific examples of successful resilience strategies around climate change and stressors. Gender, community organization, and community building through dialogue forums are key concepts that have stood out from the literature on this subject. Jan Sendzimir et al. (2011) note that good governance and resilience go hand in hand, you cannot have resilience measures in place unless you also have structures of good governance. If a country already has a structure of good governance in place, then it is highly likely that there will also be a good program of resilience already in place (Sendzimir et al., 2011).

Resilience and resilience building/programming are among the main objectives that relief and humanitarian aid organizations are 
trying to accomplish in developing countries. Timothy Frankenberger (2012) writes that simply being able to bounce back from a crisis is not enough. Developing countries that have endured a crisis must have a resilience programming that enables them to not only recover from crises but also avoid crises altogether as well as improve their national wellbeing overall and bring themselves out of poverty (Frankenberger, Enhancing Resilience to Food Insecurity and Protracted Crisis, 2012).

\section{Gender}

The literature shows that the role women play at the household and community levels is critical to the success of a resilience strategy. Mercy Corps (2014), in their resilience strategy for the Sahel, describe:

Djoundi and Brockhaus conducted six single gender participatory workshops using PRA in two communities in Lake Faguibine area in Northern Mali, they discovered that often, "women have a long term perspective focused on educational investments and non-ecosystem based strategies.

Women throughout the Sahel region lack decision-making power concerning household livelihood strategies, access to and decisionmarking power over productive resources, control over use of income, leadership opportunities within their communities, use of their time, and control over their own reproductive health decisions, including birth spacing and family planning (Mercy Corps, "Sahel Resilience Strategy, Fiscal Year 2014,” p. 2).

A good governance framework that incorporates programs such as school—based meal programs and women—led village savings and loan associations will translate into female empowerment and will create greater livelihood diversification and climate adaptation. Djoundi and Brockhaus (2014) conducted six single gender 
participatory workshops using PRA in two communities in Lake Faguibine area in Northern Mali, they discovered that often, "women have a long term perspective focused on educational investments and non--ecosystem based strategies” (Djoudi and Brockhaus, p. 133). Therefore, as education is available to women and their children the likelihood of resilience based on different means of livelihood after climate stress such as drought, is higher.

Djoudi and Brockhaus (2014) also explain the different livelihood types and activities before and after drought have dramatically changed in the last 10 years (See graph in Appendix A). These changing livelihoods have shifted from water based to forest and livestock based, and those shifts have affected women's social roles and daily life. Djoudi and Brockhaus (2014) argue this has increased the daily vulnerability of women due to "restricted food availability and greater health risk" (p. 128). Similarly, the reestablished local associations that lead to participation and community rebuilding in areas like Gao and Timbuktu, have helped increase income generating and market gardening activities (Mercy Corps, “Mali: Gender Context Analysis, June 2013”).

Mercy Corps (2013) believes it is critical to promote the inclusivity of women, among others, in their principles guiding resilience enhancement. Also, by "creating greater opportunity for their involvement in key institutions and decision-making processes"; Mercy Corps hopes to empower women (Mercy Corps, "Sahel Resilience Strategy, Fiscal Year 2014,” p. 8). As noted by Djoudi and Brockhaus (2014), gender relations are in flux due to the "forced migration of men and the emergence of new roles and responsibilities for women" (Djoudi and Brockhaus, p. 132). Thus question of whether this opportunity gap results in women empowerment would be dependent on the facilitation of local and national governments to create policies, such as the access to basic services and productive assets, that enhance and empower women (Djoudi and Brockhaus, p. 
132; Mercy Corps, “Sahel Resilience Strategy, Fiscal Year 2014,” p. 10).

\section{Community Organization}

The community organization of gender plays a large role in creating resilience at the household, individual, and community level. This means that women need to be able to build up their own social capital, which in turn builds up their personal resilience. Jules Pretty and Hugh Ward define social capital as comprising "relations of trust, reciprocity, common rules, norms and sanctions, and connectedness in institutions" (Pretty and Ward, 2001). One way of building a woman's social capital is by her utilizing her already present bodily capital (Murray, 2012). Murray (2012) defines bodily capital as a woman's physical attractiveness, strength, and fertility and the subsequent uses of that bodily capital to overcome certain shocks and stressors. Murray (2012) documents this utilization of bodily capital in her long-term case study of a group of women in Burkina Faso. These women would be married for the sole purpose of getting pregnant and giving birth to many children while also carrying out the many domestic activities reserved for wives. These many and laborious activities expected of women caused them to have extreme levels of stress which could at times interfere with their pregnancy. Murray (2012) notes that women became fed up with their husbands, cowives, or in-laws, and would then leave their homes and return to live with their parents.

Women in Burkina Faso built up their personal bodily capital by reclaiming some agency over their own lives. With the building up of bodily capital, women in Burkina Faso were better able to exploit social capital in order to make them more resilient to any problems they may face (Murray, 2012). This resulted in these women also increasing their personal resilience because when they are under stress they have a way to get away and recover from said stressors through 
demanding that certain concessions be made to make their lives more tolerable and stress free (Murray, 2012).

Frankenberger et al. (2012) argues that women in many developing nations experience endemic gender inequality in decision making over productive resources, control over household income, and leadership roles in their communities (2012, p. 10). Women can play a very important role in the building of resilience at the individual/household level and even at the community level. To do so Frankenberger et al. (2012) writes that women's access to productive assets and strengthening their decision making in both community and household affairs needs to be fully realized (Frankenberger et al., 2012, p. 8; see Appendix 3). As stated earlier women need to be given leadership roles in community savings and loan programs, and in the education of their children to become capable of supporting themselves without being dependent on the surrounding natural resources which can be susceptible to many different shocks and stressors (Djoudi and Brockhaus, 2011; see Appendix 2).

\section{Community Building through Dialogue}

A key element to building good governance and the resulting resilience of a community is to have "rich intra and inter-communal relationships” (Frankenberger, Swallow, Mueller, Spangler, Downen and Alexander, S., 2013, p. 15). Conflict resolution forums have proven to be a place where this type of communal relationship can be fostered because they encourage citizen engagement and participation while also resolving local disputes non-violently (see Appendix 2). An example of these communal forums is the 'peace communities', which have proven to be rather effective in the region around the Carare River of Colombia (Kaplan, 2013). The local population set up forums to foster a dialogue in order to make sure that non-combatants caught between the various warring factions would remain unharmed and maintain their non-combatant status (Kaplan, 2013). Kaplan writes 
that communities that did not have dialogue forums had miscommunication or no communication that led to suspicion, and mistaken actions were taken against civilians (Kaplan, 2013).

Similarly we find that griot or nyamakalas (traditional storytellers) provide a forum for dialogue that has unique aspects. They use a comical tone to dispute mediation where they ease tension and discuss difficult topics through a method called "laughing cousins" (Bauman, 2013, p. 10). Laughing cousins are a way to mediate interpersonal disputes while also trying to avoid offending either party to the dispute, thus allowing the parties (particularly the offending party) to save face and maintain their dignity (Bauman, 2013, p. 10). Storytellers are capable of producing incredible results such as being able to mediate conflicts between farmers and cattle herders in the border region between Mali and Guinea; and more recently the March 2013 coup d'état (Bauman, 2013, p. 11). Although storytellers have been very effective at defusing conflict, they have been weakened by outside interference (Bauman, 2013, p. 10).

Dialogue forums can also be used to coordinate disaster relief efforts (see Appendix 3). These forums would become a familiar gathering place for the local population(s) to ask for and give the requested aid needed for them to recover from shocks/stressors (Frankenberger, Swallow, Mueller, Spangler, Downen, and Alexander, S., 2013, p. 16). The idea is that unaffected communities can assist those communities that have been met with disaster and help them recover, adapt, and improve from their degraded state (see Appendix 2). These dialogue forums can be switched from resolving interpersonal disputes to also serving as an institutional memory for preserving certain techniques that have proven useful in recovering from a disaster (see Appendix 2).

In order for meaningful community organization and community building through dialogue to take place, the different levels of government in the countries that are being targeted for improved good 
governance and resilience programming, need to at the very least not to interfere with the local level initiatives for good governance and resilience initiatives (Sendzimir, 2011). An example of a negative interference effect of government interference is the weakening of the storytellers, which would otherwise continue to have a significant impact in dialogue creation (Bauman, 2013, p. 10). If the different levels of government wish to be included and involved in good governance and resilience initiatives, then they must make a positive good faith effort to assist and provide their many localities with access to the required agencies and resources (Sendzimir, 2011).

Our research on good governance and resilience at the individual and household level has included three major themes: gender, community organization, and community building through dialogue. These three areas of research have led us to consider citizen engagement, participation and dispute resolution as the main goal of good governance at the individual level. Once citizens are engaged and are participating, they can make better use of the bonding, bridging and linking social capital available to them (Frankenberger, Swallow, Mueller, Spangler, Downen, and Alexander, S., 2013, p. 15). Aldrich defines bonding social capital as that within/between community members, bridging social capital as the connection to members or networks outside of the immediate community, and linking social capital as the makeup of 'networks of trusting relationships between people who are interacting across explicit, formal or institutionalized power or authority gradients in society (Aldrich, 2012, p. 655).

Good governance at the bonding level includes school-based programs, community building dialogue forums, as well as women led village savings and loan associations. At the bridging level, we find it is important to have communal activities in place, such as peace communities and empowered storytellers, that will allow for unaffected communities and affected communities to already have 
infrastructure for support (see Appendix 2) as well as non-conflict forming discussions between farmers and cattle herders (Bauman, 2013, 10). These infrastructures will allow for goods exchange and market accessibility that can be accessed once a community gets hit with a climate stress (Frankenberger, T. R., Spangler, T., Nelson, S., and Langworthy, M., 2012). At the linking level we find that awareness of NGOs and formal government agencies providing access to education and health care is the critical step to connect the individual and the household to the larger community level of governance (see Appendix 2).

\section{Conclusion}

This literature review has examined the linkages between good governance and resilience at the national/regional, community, and individual/family levels. By necessity, it highlights certain factors that recur in the literature as dominant themes, while leaving out many of the factors that could additionally be mentioned. Our attention has been given to the question of how state and societal actors can restructure and reorganize their governance systems in order to enhance resilience in the face of increasingly severe natural and manmade shocks and stresses. We have centered the discussion on the critical role of social capital in making governance systems at all levels work better, including for the purposes of resilience.

We have also paid particular attention to the importance of both formal and informal institutions, noting the ways in which the latter are often more important in the sorts of contexts we describe here. Finally, we have highlighted the inextricable link at all levels of governance between achieving resilience and achieving socioeconomic development and opportunity. Just as we note how resilience is almost always found in the presence of good governance, so too resilience is almost always found in the presence of widespread and equitable development opportunities for all members of society. 
Anthós, Vol. VI, Issue 1

\section{Appendix 1}

Djoudi, H, and M Brockhaus, p. 129.

Figure 1. Shifting livelihoods and the resulting gendered repartition of livelihood activities before and after the drying out of Lake Faguibine.

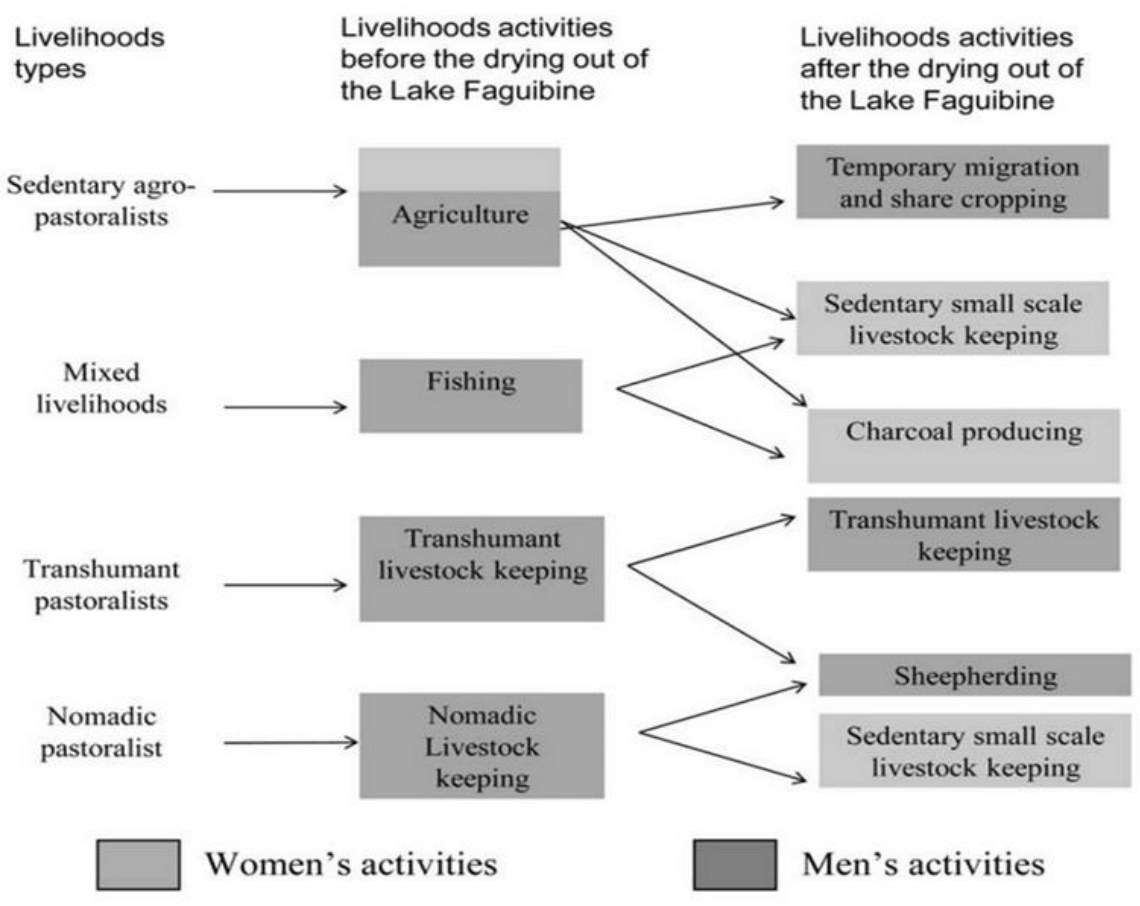




\section{Appendix 2}

Frankemberger, Swallow, Mueller, Spangler, Downen, and Alexander, S. (2013).

\section{Table 1. Social Capital and Key Capacities for Achieving Community} Resilience, p. 16-17.

\begin{tabular}{|c|c|c|c|}
\hline & Bonding Social Capital & Bridging Social Capital & Linking Social Capital \\
\hline 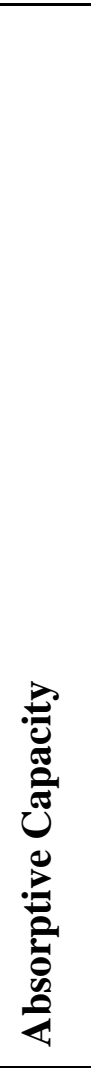 & $\begin{array}{l}\text { Evident in informal } \\
\text { social protection: } \\
\text { - } \quad \text { Community-based } \\
\text { early warning } \\
\text { - } \quad \begin{array}{l}\text { Community-based } \\
\text { dissemination/diffu }\end{array} \\
\text { sion of critical } \\
\text { information (e.g., } \\
\text { plans/available } \\
\text { resources in the } \\
\text { face of a disaster, } \\
\text { post-disaster } \\
\text { entitlements) } \\
\text { Community-based } \\
\text { risk sharing (e.g., } \\
\text { savings and credit } \\
\text { groups, funeral } \\
\text { associations) } \\
\text { Sharing other } \\
\text { resources (food, } \\
\text { cash/loans, labor, } \\
\text { child care, tools, } \\
\text { transportation) } \\
\text { Bonding social capital } \\
\text { works well for } \\
\text { idiosyncratic risks, when } \\
\text { only one or a few } \\
\text { households are } \\
\text { potentially affected: they } \\
\text { can turn to unaffected } \\
\text { households. }\end{array}$ & $\begin{array}{l}\text { Evident in community-to- } \\
\text { community support during } \\
\text { disasters: } \\
\text { Unaffected } \\
\text { communities share } \\
\text { resources with } \\
\text { disaster-affected ones } \\
\text { (e.g. remittances) } \\
\text { Unaffected } \\
\text { communities share } \\
\text { knowledge, expertise, } \\
\text { and networks based on } \\
\text { their own experiences } \\
\text { of similar shocks. } \\
\text { Inter-communities } \\
\text { communication/s } \\
\text { haring of technologies } \\
\text { and innovations/ } \\
\text { Bridging social capital } \\
\text { works well for covariate } \\
\text { risks: unaffected } \\
\text { communities can support } \\
\text { communities that have } \\
\text { experiences or are } \\
\text { vulnerable to a shock. }\end{array}$ & $\begin{array}{l}\text { Community-based } \\
\text { organizations formed in } \\
\text { response to disasters can } \\
\text { provide community } \\
\text { members with a voice and } \\
\text { leverage in decision-making } \\
\text { in externally-supported } \\
\text { rebuilding efforts. } \\
\text { Linking social capital } \\
\text { facilitates a feedback loop } \\
\text { between grassroots and } \\
\text { policy/formal governance } \\
\text { regarding covariate risks, } \\
\text { e.g. } \\
\text { - Collaboration over } \\
\text { climate information } \\
\text { gathering and } \\
\text { dissemination: } \\
\text { government agencies, } \\
\text { research institutions, } \\
\text { media }\end{array}$ \\
\hline
\end{tabular}




\begin{tabular}{|c|c|c|c|}
\hline & Bonding Social Capital & Bridging Social Capital & Linking Social Capital \\
\hline 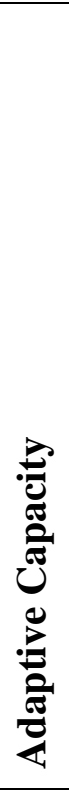 & $\begin{array}{l}\text { Bonding social capital is } \\
\text { more limited in } \\
\text { applications to adaptive } \\
\text { capacity. Exceptions } \\
\text { include: } \\
\text { - Close relationships } \\
\text { between } \\
\text { community } \\
\text { members facilitate } \\
\text { adoption of proven } \\
\text { practices for } \\
\text { income generation, } \\
\text { health and } \\
\text { nutrition, and } \\
\text { climate change. } \\
\text { Women-led Village } \\
\text { Savings and Loan } \\
\text { Associations can } \\
\text { promote women’s } \\
\text { empowerment, } \\
\text { greater livelihood } \\
\text { diversification, and } \\
\text { climate adaptation. }\end{array}$ & $\begin{array}{l}\text { Bridging social capital } \\
\text { facilitates dissemination } \\
\text { and multiplier effects of } \\
\text { proven good practices. } \\
\text { Formal and/or informal } \\
\text { ties between communities } \\
\text { in different agro- } \\
\text { ecological zones can } \\
\text { contribute to livelihood } \\
\text { diversification and } \\
\text { protection from adverse } \\
\text { seasonal trends affecting } \\
\text { agricultural productivity. } \\
\\
\text { Exposure to models and } \\
\text { experiences in other } \\
\text { communities can inform } \\
\text { and broaden aspirations } \\
\text { and thereby encourage } \\
\text { trying new practices. }\end{array}$ & $\begin{array}{l}\text { Adaptive capacities } \\
\text { strengthened through } \\
\text { collective action can compel } \\
\text { formalization or strengthening } \\
\text { of structures that can have an } \\
\text { impact at high levels, e.g. } \\
\text { - People resettled into } \\
\text { new areas as a protection } \\
\text { measure or in the } \\
\text { aftermath of a disaster } \\
\text { form new networks and } \\
\text { institutions (farmers' } \\
\text { unions, women's } \\
\text { associations) beyond the } \\
\text { immediate community }\end{array}$ \\
\hline 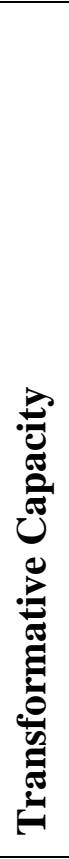 & & $\begin{array}{l}\text { Relationships forged to } \\
\text { realize one community can } \\
\text { be applied to other } \\
\text { functions: } \\
\text { - } \quad \text { Increased exposure to } \\
\text { other grounds in } \\
\text { markets (formal or } \\
\text { informal, as along } \\
\text { roadsides) can help to } \\
\text { mitigate conflict as } \\
\text { different groups } \\
\text { become more } \\
\text { familiar with each } \\
\text { other over common } \\
\text { interests. } \\
\text { School-based } \\
\text { programs (e.g. school } \\
\text { feeding and meal } \\
\text { preparation) that } \\
\text { engage families from } \\
\text { otherwise warring } \\
\text { factions can improve } \\
\text { their } \\
\text { interrelationships and } \\
\text { reduce antagonism }\end{array}$ & $\begin{array}{l}\text { Strong vertical linkages are } \\
\text { essential to realizing } \\
\text { transformative capacities. } \\
\text { These are evidenced in areas } \\
\text { such as: } \\
\text { - } \quad \text { Infrastructure } \\
\text { investment } \\
\text { - } \quad \text { Land } \\
\text { - } \quad \text { Reform } \\
\text { - } \quad \text { Pro-poor policies } \\
\text { - } \quad \text { Government } \\
\text { accountability } \\
\text { mechanisms } \\
\text { Equitable allocation of } \\
\text { entitlements } \\
\text { Policies informed by } \\
\text { representative } \\
\text { participation of different } \\
\text { community sectors } \\
\text { (socio-cultural groups; } \\
\text { women/men; } \\
\text { elderly/youth; disabled) }\end{array}$ \\
\hline
\end{tabular}




\section{Appendix 3}

Frankenberger, T. R., Spangler, T., Nelson, S., and Langworthy, M. (2012). Enhancing Resilience to Food Insecurity amid Protracted Crisis. Food Insecurity in Protracted Crises, Box 5, p. 8.

\section{Box 5: Principles of Resilience Programming for Protracted Crises}

- Support a transition, over time, in the balance of effort and resources from humanitarian assistance toward longer-term disaster risk management, climate change adaptation, livelihood diversification, and social protection;

- Recognize and respond to the different needs, capabilities and aspirations of the most vulnerable groups (women, orphans, elderly, displaced, conflict-affected, unemployed/uneducated youth);

- Promote healthy ecosystems through ecosystem-based planning, payment for ecosystem services (PES), and support for farmer managed natural regeneration (FMNR):

- Support greater investment in human capital to enable households to maintain health, diversify livelihood options, build social capital and exercise their individual and collective rights;

- Enable community participation by identifying and engaging customary institutions and valuable forms of traditional knowledge for coping with climate variability, conflict, and food insecurity;

- Advocate for and support more effective formal and informal governanœe, peace-building and conflict mitigation;

- Based on thorough risk assessment (including analysis of local political economies and drivers of conflict), facilitate livelihood diversification in response to actual (and potential shocks):

- Enable greater gender equity by enhancing women's access to productive assets and strengthening their roles in community and household decision-making:

- Improve access to public and productive infrastructure (roads, markets, water infrastructure, power, etc.), access to financial services and greater participation in markets ${ }^{25}$;

- Strengthen market participation by enabling profitable engagement of smallholders in value chains;

- Look for means of developing strategic partnerships (including with the private sector) in order to complement donor funding and provide financial incentives for investment in livelihoods; and

- Contribute to improved knowledge management by addressing key knowledge gaps and documenting evidence of promising resilience-building practices.

\section{Works Cited}

“2012 Investment Climate Statement - Mali.” U.S. Department of State. U.S.

Department of State, 2012. Web. 28 Feb. 2014.

Adikari, Y., R. Osti, and K. Hiroki. "Governance, Socio-Economic and Geophysical Indices for Determining Water-Related Disaster Risk.” Water Policy 15.2

(2013): 179-192. Web. 28 Feb. 2014.

Aldrich, Daniel. Building Resilience: Social Capital in Post-Disaster Recovery.

Chicago: University of Chicago Press, 2012. Print. 
Allen, R. "Guide to Good Governance Programming.” Mercy Corps. Mercy Corps., 2010. Web. 28 Feb. 2014.

Ballard, Heidi L., and Jill M. Belsky. "Participatory Action Research and Environmental Learning: Implications for Resilient Forests and Communities.” Environmental Education Research 16.5-6 (2010): 611-627. Print.

Baumen, Peter. "Barriers and Drivers to Resilience in Mali: A Conflict Perspective.” 2013. Web. 28 Feb. 2014.

Benjaminsen, Tor A., Koffi Alinon, Halvard Buhaug, and Jill Tove Buseth. "Does Climate Change Drive Land-use Conflicts in the Sahel?” Journal of Peace Research 49.1 (2012): 97-111. Print.

Boyd, Emily, and Carl Folke. Adapting Institutions: Governance, Complexity, and Social-Ecological Resilience. Cambridge: Cambridge UP, 2012. Print.

Briguglio, Lino, Gordon Cordina, Nadia Farrugia, and Stephanie Vella. "Economic Vulnerability and Resilience: Concepts and Measurements.” Oxford Development Studies 37.3(2009): 229-247. Web. 28 Feb. 2014.

Brown, Julia. "Assuming Too Much? Participatory Water Resource Governance in South Africa.” Geographical Journal 177.2 (2011):171-185. Web. 28 Feb. 2014. Calleja, A. "Procurement Beyond Award: On the Integration of Governance Principles when Executing Public Private Partnerships.” European Procurement and Public Private Partnership Law Review 8.4(2013): 294-301. Web. 28 Feb. 2014.

Clement , Floraine. “Analysing Decentralised Natural Resource Governance: Proposition for a 'Politicised' Institutional Analysis and Development Framework.” Policy Sciences 43.2 (2010): 129-156. Web. 28 Feb. 2014. "Country Reports on Human Rights Practices for 2012." U.S. Department of State. US Department of State, 2012. Web. 28 Feb. 2014.

“Defining Disaster Resilience: A DFID Approach Paper.” UK Department for International Development. UK Department for International Development, 2011. Web. 28 Feb. 2014.

Djoudi , H., and M. Brockhaus. "Is Adaptation to Climate Change Gender Neutral? Lessons from Communities Dependent on Livestock and Forests in Northern Mali.” International Forestry Review 132 (2011): 123-135. Web. 28 Feb. 2014. Evans, Mel, and Stephen Syrett. "Generating Social Capital?: The Social Economy and Local Economic Development.” European Urban and Regional Studies 14.1 (2007): 55-74. Web. 28 Feb. 2014.

Frankenberger, Tim. Interview by Pi Sigma Alpha Taskforce. Work of Tango International. February 2014. 
Frankenberger, Tim, Monica Mueller, Tom Spangler, and Sara Alexander.

"Community Resilience: Conceptual Framework and Measurement: Feed the

Future Learning Agenda.” The U.S. Government's Global Hunger and Food

Security Initiative, United States Agency for International Development,

United States Agency for International Development. United States

Government, 2013. Web. 28 Feb. 2014.

Frankenberger, Timothy, K. Swallow, M. Mueller, T. Spangler, J. Downen, and S.

Alexander . "Feed the Future Learning Agenda Literature Review: Improving

Resilience of Vulnerable Populations." Feed the Future. TANGO

International, 2013. Web. 28 Feb. 2014.

Frankenberger, Timothy, T. Spangler, S. Nelson, and M. Langworthy. "Enhancing

Resilience to Food Insecurity amid Protracted Crisis.” Food Insecurity in

Protracted Crises. TANGO International, 2012. Web. 28 Feb. 2014.

Gallopin, G. "The Linkages between Vulnerability, Resilience, and Adaptive

Capacity.” Potsdam Institute for Climate Impact Research, 2007. Web. 28

Feb. 2014.

Garden, Po. Lebel, Louis. Imamura, Masao. Chiang Mai University. "The Politics

of Scale, Position, And Place in Governance of Water Resources in the

Mekong Region.” Ecology and Society 10.2 (2005): 18. Web. 28 Feb. 2014.

"Gender Assessment: Context Analysis.” Mercy Corps. Mercy Corps., 2013.Web. 28

Feb. 2014.

Grove, A. T. "Geographical Introduction to the Sahel.” The Geographical

Journal 144.3 (1978): 407-15. Print.

Guth James L. John C. Green, Lyman A. Kellstedt and Corwin E. Smidt. "Faith and the Environment: Religious Beliefs and Attitudes on Environmental Policy." American Journal of Political Science 39.2 (1995): 364-382.

Haggblade, Steven. "Unscrambling Africa: Regional Requirements for Achieving Food Security.” Development Policy Review 31.2 (2013). Web. 28 Feb. 2014.

Hou, Jeffrey, and Isami Kinoshita. "Bridging Community Differences through

Informal Processes: Reexamining Participatory Planning in Seattle and

Matsudo.” Journal of Planning Education and Research 26.3 (2007): 301-314.

Print.

“IIP Digital | U.S. Department of State.” United States Agency for International

Development (USAID) Integrates Humanitarian, Development Aid for

Resilience. USAID, 2012. Web. 28 Feb. 2014.

Kaplan, O. "Protecting Civilians in Civil War: The Institution of the ATCC in

Colombia.” Journal of Peace Research 50.3 (2013): 351-367. Web. 28 Feb. 2014. Mirumachi, N., and E. Van Wyk. "Cooperation at Different Scales: Challenges for 
Local and International Water Resource Governance in South Africa.” Geographical Journal 176.1 (2010): 25-38. Web. 28 Feb. 2014.

Murray, S.F., M.S. Akoum, and K.T. Storeng. "Capitals Diminished, Denied, Mustered and Deployed: A Qualitative Longitudinal Study of Women's Four Year Trajectories after Acute Health Crisis, Burkina Faso.” Social Science and Medicine 75.12 (2012): 2455-2462. Web. 28 Feb. 2014.

Nanda, Ved. “The 'Good Governance’ Concept Revisited.” Annals of the American Academy of Political and Social Science 603.1 (2006): 269-283.

Niang, Amy. "The (In)Commodities of Laissez-Faire Integration: Trae and Mobility in a Cross-Border Market.” African Studies 72.1 (2013): 41-63. Web. 28 Feb. 2014.

Nichols, James D., Mark D. Koneff, Patricia J. Heglund, Melinda G. Knutson, Mark G. Seamans, James E. Lyons, John M. Morton, Malcom T Jones, G. Scott Boomer and Byron K. Williams. "Climate Change, Uncertainty, and Natural Resource Management.” Journal of Wildlife Management 75.1 (2011): 6-18. Web. 28 Feb. 2014.

Nyirenda, J. C., and R. A. Cropf. "The Prospects for eGovernment and eGovernance in Sub-Saharan Africa: A Case Study of Zambia.” International Journal of Electronic Government Research 6.1 (2010): 23-45. Web. 28 Feb. 2014.

Pellini, Arnaldo, and David Ayres. "Community Participation in Local Governance in Cambodia: Learning from the Village Networks Approach.” Development in Practice 17.3 (2007): 404-409. Print.

Pingali, Prabhu, Luca Alinovi, and Jacky Sutton. "Food Security in Complex Emergencies: Enhancing Food System Resilience.” Disasters 29 (2005): S5-S24. Print.

Pretty, J., and H. Ward. "Social Capital and the Environment.” World Development 29.2 (2011): 209-227. Web. 28 Feb. 2014.

“Principles of Resilience.” Mercy Corps. Mercy Corps., 2013. Web. 28 Feb. 2014. Robards, Martin, and Lilian Alessa. "Timescapes of Community Resilience and Vulnerability in the Circumpolar North.” Artic 57.4 (2004): 415-427. Print.

"Sahel Resilience Strategy.” Mercy Corps. Mercy Corps., 2014. Web. 28 Feb. 2014. Sendzimir, J., C. Reij, and Magnuszewski. "Rebuilding Resilience in the Sahel: Regreening in the Maradi and Zinder Regions of Niger.” Ecology and Society 16.3 (2011). Web. 28 Feb. 2014.

Sheikh, Kashif M. "Involving Religious Leaders in Conservation Education in the Western Karakorum, Pakistan.” Mountain Research and Development 26.4 (2006): 319-22. Print. 
Sickmiller, Byron. "Social Vulnerability to Natural Disasters.” MA thesis. U of Cincinnati, 2007. Web. 28 Feb. 2014.

Tougiani, A., C. Guero, and T. Rinaudo. "Community Mobilisation for Improved Livelihoods through Tree Crop Management in Niger.” GeoJournal 74.5 (2009): 377-389. Web. 28 Feb. 2014.

Turner, Matthew D. "Climate Change and Social Resilience: 'Adaptive' Conflict in the Sahel.” Berkeley Environmental Politics Workshop 20 (2012). Web. 28 Feb. 2014.

Twigg, J. “Characteristics of a Disaster-Resilient Community.” Department for International Development (DFID) Disaster Risk Reduction. DFID, 2007. Web. 28 Feb. 2014.

"Understanding Community Resilience and the Factors that Strengthen Them.” International Federation of Red Cross and Red Crescent (FRC). FRC, 2011. Web. 28 Feb. 2014.

"What is Good Governance?” Economic and Social Commission for Asia and the Pacific. United Nations, Web. 28 Feb. 2014.

Wagle, Udaya R. "Political Participation and Civic Engagement in Kathmandu: An Empirical Analysis with Structural Equations." International Political Science Review 27.3 (2006): 301-322. Print.

“Working Paper.” Dansk Institute for Internationale Studeir (DIIS). DIIS, 2010. Web. 28 Feb. 2014.

Zolli, Andrew and Ann Marie Healy. Resilience: Why Things Bounce Back. Simon and Schuster, 2013. Kindle Edition. Web. 28 Feb. 2014. 